\title{
Pemanfaatan Cangkang Rajungan (Portunus pelagicus. sp) dan Eceng Gondok Sebagai Sumber Kalsium Pada Pakan Ayam
}

\section{Utilization of Small Crab Shells (Portunus pelagicus sp.) and Water Hyacinth as a Source of Calcium in Chicken Feed}

\author{
Muhammad Iqbal Hamka, Program Studi Pendidikan Teknologi Pertanian, Universitas \\ Negeri Makassar. Email: iqbalhamka230@ gmail.com \\ Muhammad Wiharto Caronge, Program Studi Pendidikan Teknologi Pertanian, Universitas \\ Negeri Makassar. Email: wiharto09@gmail.com \\ Ratnawaty Fadilah, Program Studi Pendidikan Teknologi Pertanian, Universitas Negeri \\ Makassar. Email: ratnamangrove@ gmail.com
}

\begin{abstract}
Abstrak
Penelitia $\mathrm{n}$ ini bertujuan untuk mengetahui kandungan nutrisi pakan ayam berbahan baku cangkang rajungan (Portunus pelagicus sp.) dan eceng gondok. Penelitian ini menggunakan metode rancangan acak lengkap (RAL) 4 perlakuan dengan mensubstitusi tepung ikan, yaitu $\mathrm{K}$ (Tepung ikan 30\%, cangkang rajungan 0\%, dan eceng gondok 0\%), A (Tepung ikan 10\%, cangkang rajungan $20 \%$, dan eceng gondok 0\%), B (Tepung ikan 10\%, cangkang rajungan $10 \%$, dan eceng gondok $10 \%$ ), $\mathrm{C}$ (Tepung ikan $10 \%$, cangkang rajungan $0 \%$, dan eceng gondok $20 \%$ ). Penelitian ini terdiri dari dua tahap, yaitu pertama adalah pembuatan cangkang rajungan (Portunus pelagicus sp.) yang bersih dikeringkan selama \pm 8 jam, kemudian ditepungkan menggunakan ayakan 80 mesh, sedangkan pembuatan tepung eceng gondok dikeringkan selama \pm 8 jam lalu ditepungkan. Tahap kedua adalah membuat pakan sesuai dengan formulasi dan kemudian hasilnya diuji proksimat mencakup kandungan protein, lemak, kalsium, dan kadar air. Hasil penelitian menunjukkan bahwa substitusi pakan berbahan baku tepung cangkang rajungan (Portunus pelagicus sp.) dan eceng gondok memiliki pengaruh yang sangat signifikan terhadap kandungan nutrisi pada pakan ayam. Hasil uji penelitian ini menunjukkan bahwa perlakuan yang terbaik yang mendekati standar SNI pakan ayam adalah perlakuan C. Kandungan nutrisi pada perlakuan ini adalah protein $26,32 \%$, lemak $3,42 \%$, kalsium $1,35 \%$, dan kadar air $4,12 \%$.
\end{abstract}

Kata Kunci: pakan ayam, tepung ikan, tepung cangkang rajungan, eceng gondok, proksimat

\section{Abstract}

This study aims to determine the nutritional content of chicken feed made from raw crab shells (Portunus pelagicus sp.) and water hyacinth. This study uses a completely randomized design (CRD) 4 treatment by substituting fish meal, namely $K(30 \%$ fish meal, $0 \%$ crab shell, and $0 \%$ water hyacinth), A (10\% fish flour, 20\% crab shell), and $20 \%$ crab shell $0 \%$ water hyacinth, B (10\% fish meal, 10\% crab shell, and 10\% water hyacinth), C (10\% fish flour, $0 \%$ crab shell, and 20\% water hyacinth shell). This research consists of two stages, first is the making of crab shells (Portunus pelagicus sp.) Which is clean dried for \pm 8 hours, then deposited using 80 mesh sieves, while the manufacture of water hyacinth flour is dried for \pm 8 hours and then deposited. The second step is to make the feed according to the formulation and then the results in a proximate test include protein, fat, calcium, and water content. The results showed that the substitution of feed made from raw crab shell (Portunus pelagicus sp.) and 
water hyacinth had a very significant effect on the nutritional content of chicken feed. The test results of this study showed that the best treatment approaching the SNI standard for chicken feed was treatment $C$. The nutrient content in this treatment was $26.32 \%$ protein, $3.42 \%$ fat, $1.35 \%$ calcium, and $4.12 \%$ water content.

Keywords: chicken feed, fish meal, small crab shell flour, water hyacinth, proximate

\section{Latar Belakang}

Seiring dengan perkembangan populasi ternak maka kebutuhan akan pakan juga terus mengalami peningkatan. Dalam rangka memenuhi kebutuhan pakan unggas tidak hanya dituntut dalam pencapaian aspek kualitas saja, akan tetapi yang lebih penting adalah memproduksi pakan yang ekonomis, murah, dan terjangkau oleh peternak (Bintang et al., 2007).

Pakan merupakan faktor yang memegang peranan sangat penting dan menentukan dalam keberhasilan usaha peternakan. Menurut Dani et al. (2005), biaya pakan ini dapat mencapai $60-70 \%$ dari komponen biaya produksi, sehingga salah satu alternatif yang dapat dilakukan untuk menekan biaya produksi tersebut adalah dengan membuat pakan buatan sendiri. Dalam memproduksi pakan ternak, sebagian bahan dasar utama pakan masih tergantung pada kedelai yang harganya relatif tinggi dan masih harus didatangkan melalui impor.

Disisi lain, distribusi pakan ternak komersil untuk ayam dari pabrik ke peternak memiliki mata rantai yang sangat Panjang. Hal ini membuat harga jual ditingkat sub-agen atau penjual pakan menjadi mahal. Efek lainnya adalah terkadang kualitas pakan yang dijual sudah menurun sebab proses penyimpanan yang kurang mendapatkan perhatian. Mengingat kendala-kendala tersebut salah satu upaya yang efektif dalam rangka menghemat biaya produksi budidaya ternak ayam adalah perlu adanya alternatif sebagai sumber pakan lokal. Pemanfaatan limbah dan gulma sebagai pakan alternatif merupakan salah satu cara untuk menanggulangi keadaan tersebut.

Upaya ini dilakukan dengan memanfaatkan bahan baku pakan yang murah dan mudah didapat dan tidak bersaing dengan kebutuhan manusia. Selain murah dan mudah didapat, faktor yang penting untuk diperhatikan dalam pembuatan pakan adalah nutrisi yang terkandung pada bahan tersebut. Ransum ternak unggas perlu mengandung kalsium dan fosfor.

Menurut Efendi (2011), ransum ternak unggas perlu mineral dalam jumlah yang cukup terutama kalsium dan fosfor, karena 70\%-80\% mineral tubuh terdiri dari kalsium dan fosfor. Kalsium dan fosfor berfungsi didalam pembentukan tulang, komponen asam nukleat, keseimbangan asam-basa, koordinasi otot, metabolisme jaringan syaraf, serta terlibat dalam metabolisme karbohidrat, lemak, dan protein. Suatu mineral (kalsium, fosfor, natrium, kalium, klorida) jarang menyebabkan kematian tetapi berpengaruh langsung terhadap kesehatan ternak. Oleh karena itu, salah satu limbah yang memiliki kandungan kalsium tinggi dan dapat dimanfaatkan sebagai bahan pakan adalah cangkang rajungan.

Rajungan (Portunus pelagicus) merupakan salah satu komoditas perikanan yang memiliki nilai ekonomis yang cukup 
tinggi (BPPMHP, 2000). Rajungan juga merupakan komoditas ekspor yang permintaannya dari tahun ke tahun semakin meningkat. Sampai saat ini, seluruh kebutuhan ekspor rajungan masih mengandalkan dari hasil penangkapan di laut, sehingga dikhawatirkan akan mempengaruhi jumlah populasinya di alam (Irnawati, 2017).

Salah satu upaya yang dapat dilakukan untuk mengatasi keberadaan limbah cangkang rajungan, yaitu diolah menjadi pakan ternak dalam bentuk tepung sebagai sumber kalsium. Menurut Hidayat (2017), cangkang rajungan memiliki $19,97 \%$ kalsium dan $1,81 \%$ fosfor. Disamping itu menurut Kusumawati (2014), limbah rajungan (rajungan) kaya akan protein $(32,95 \%)$, serat kasar $(10,89 \%)$, kalsium $(22,93 \%)$, dan fosfor $(0,78 \%)$.

Selain cangkang rajungan, eceng gondok yang biasanya dianggap hanya sebagai gulma pun ternyata dapat dijadikan sebagai pakan alternatif untuk memperkaya kandungan nutrisi pada pakan. Menurut Mahmilia (2005) dalam hasil analisis kimia Laboratorium Gizi Dasar, Fakultas Peternakan Universitas Andalas didapatkan komposisi tepung eceng gondok dalam bentuk bahan kering yaitu protein kasar 6,31\%, lemak kasar 2,83\%, serat kasar 26,61\%, Ca dan P masing-masing 0,47 dan $0,66 \%$, abu $16,12 \%$, serta BETN $48,14 \%$. Namun dalam penggunaannya sebagai ransum unggas sangat terbatas, karena bahan ini mempunyai kandungan gizi yang rendah dengan kadar serat kasar yang cukup tinggi.

Berdasarkan kajian latar belakang di atas, maka perlu dilakukan penelitian tentang pemanfaatan cangkang rajungan dan eceng gondok sebagai sumber kalsium pada pakan ayam. Sedangkan tujuan yang ingin dicapai dalam penelitian ini adalah untuk mengetahui kandungan nutrisi pakan ayam dengan penambahan tepung cangkang rajungan dan tepung eceng gondok.

\section{Bahan dan Metode}

Bahan baku yang digunakan dalam pembuatan pakan ayam adalah tepung cangkang rajungan, tepung eceng gondok, tepung ikan, jagung, dedak padi, dan bungkil kelapa.

\section{Tahap Persiapan}

Langkah pertama dalam proses pembuatan tepung cangkang rajungan adalah melakukan penyortiran terlebih dahulu untuk memisahkan cangkang rajungan yang layak digunakan. Setelah itukdilakukan pencucian hingga bersih, dan selanjutnya cangkang dikeringkan dibawah sinar matahari selama 8 jam. Cangkang yang sudah kering dilakukan proses penepungan dengan cara dihaluskan dengan menggunakan blender sehingga didapatkan ukuran cangkang yang lebih kecil. Setelah itu dilakukan pengayakan dengan menggunakan ayakan ukuran 60 mesh.

Selanjutnya proses pembuatan tepung eceng gondok adalah diawali dengan membersihkan eceng gondok dari sisa lumpur atau kotoran-kotoran yang melekat. Lalu eceng gondok yang akan digunakan sebagai tepung dicacah terlebih dahulu untuk mempercepat proses pengeringan. Setelah dicacah lalu dikeringkan di bawah sinar matahari selama 8 jam. Kemudian setelah dianggap kering, maka langkah selanjutnya adalah menghaluskan eceng gondok dengan menggunakan blender. Langkah terakhir 
adalah mengayak tepung eceng gondok dengan ayakan 80 mesh.

\section{Pembuatan Pakan Ayam}

Proses pembuatan pakan ayam pada proses awal, masing-masing bahan baku ditimbang sesuai dengan formulasi yang telah ditentukan. Setelah ditimbang, semua bahan baku dicampur dan diayak dengan menggunakan ayakan 80 mesh. Pembuatan adonan dilakukan dengan mencampurkan semua bahan bahan baku dengan air. Perbandingan yang digunakan adalah \pm 30 $\mathrm{mL}$ air : 100 gram bahan baku adonan. Setelah itu semua bahan dicampur sampai merata, sebagai indikatornya jika adonan dikepal dapat menyatu dan tidak meneteskan air. Kemudian adonan dicetak bentuk pelet menggunakan mesin pencetak pelet dengan ukuran 0,5 cm. Dan langkah terakhir adalah menjemur peler selama 1-2 hari. Objek yang diamati pada penelitian ini adalah komponen gizi pelet hasil olahan yang meliputi kadar kalsium, protein, lemak, dan kadar air.

\section{Hasil dan Pembahasan}

\section{Kadar Protein}

Berdasarkan hasil pengujian terhadap kandungan protein pakan setiap formulasi, perlakuan $\mathrm{K}$ memiliki kadar protein tertinggi dengan nilai $30,95 \%$. Nilai protein pada pelakuan kontrol masih lebih tinggi jika dibandingkan dengan perlakuan A, B, dan $\mathrm{C}$ yang kadar proteinnya secara berturut-turut $29,44 \%, 28,50 \%$, dan 26,32\%.

Menurut SNI 01-3931-2006, standar kadar protein pakan buatan adalah 18,00$22,00 \%$. Kandungan protein pada perlakuan $\mathrm{K}$ lebih tinggi dikarenakan pada perlakuan ini digunakan tepung ikan yang memiliki kadar protein lebih tinggi dibandingkan dengan perlakuan $\mathrm{A}, \mathrm{B}$, dan $\mathrm{C}$ yang menggunakan tepung cangkang rajungan dan tepung eceng gondok sebagai sumber protein. Tingginya kadar protein pada pakan $\mathrm{K}$ dikarenakan penggunaan tepung ikan yang tinggi yaitu sebesar $30 \%$ dari ketiga perlakuan lainnya. Sebagaimana yang kita ketahui tepung ikan mempunyai kandungan protein yang tinggi yaitu berkisar 53,5\%, dan yang berasal dari limbah ikan sekira 46\% (Baye, 2015). Nilai rata-rata kandungan protein pada pakan yang dihasilkan dapat dilihat pada Gambar 1 sebagai berikut.

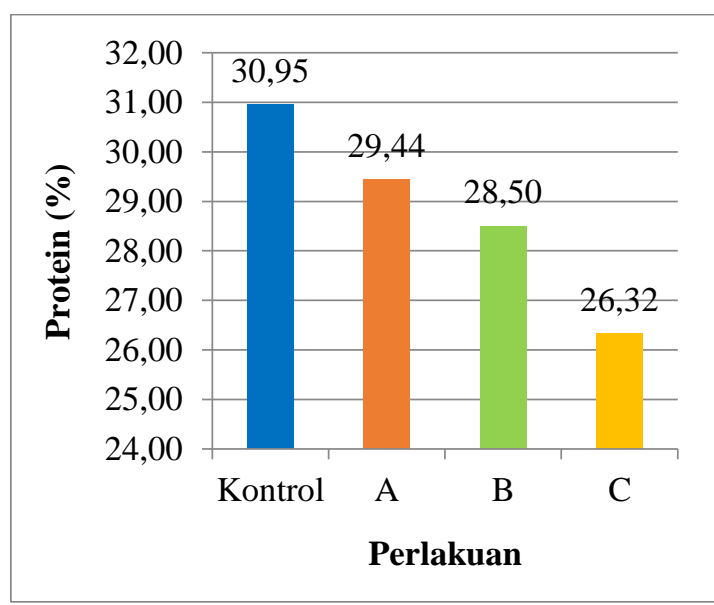

Gambar 1. Kandungan protein pakan yang dihasilkan

Keterangan:

$\mathrm{K}$ : Pakan tanpa penambahan tepung cangkang rajungan dan tepung eceng gondok.

A: Pakan dengan konsentrasi $20 \%$ tepung cangkang rajungan dan $0 \%$ tepung eceng gondok.

B: Pakan dengan konsentrasi $10 \%$ tepung cangkang rajungan dan $10 \%$ tepung eceng gondok.

C: Pakan dengan konsentrasi 0\% tepung cangkang rajungan dan $20 \%$ tepung eceng gondok. 


\section{Kadar Air}

Hasil pengujian kadar air terhadap setiap formulasi menunjukkan perlakuan perlakuan $\mathrm{K}$ memiliki kadar air tertinggi dengan nilai 4,88\%. Sedangkan berdasarkan hasil pengolahan data perlakuan B dan C memiliki kadar air dengan persentase berturut-turut adalah $3,56 \%$ dan $4,12 \%$. Nilai kadar air terendah adalah perlakuan A dengan rata-rata 2,94\%.

Tinggi rendahnya kadar air pada masing-masing perlakuan ini disebabkan oleh proses pengeringan pakan dan kandungan kadar air bahan baku sebelum diolah menjadi pakan, seperti kadar air yang terdapat pada tepung ikan teri sebesar $16,7 \%$ (Mahmud, 2009). Sedangkan kandungan kadar air pada eceng gondok sebesar 92,6\%. Bahan penyusun pakan memiliki kadar air yang lebih tinggi dari standar yang ditentukan.

Meski demikian, keempat perlakuan pakan telah memenuhi syarat maksimal kadar air pakan ayam berdasarkan SNI 013931-2006. Persentase rata-rata kandungan kadar air pada pakan yang dihasilkan ditampilkan pada Gambar 2.

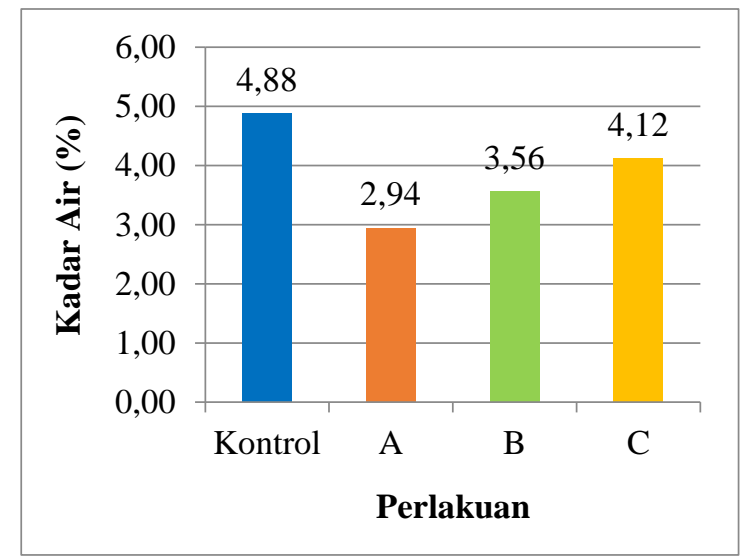

Gambar 2. Kandungan kadar air pakan yang dihasilkan
Keterangan:

K: Pakan tanpa penambahan tepung cangkang rajungan dan tepung eceng gondok.

A: Pakan dengan konsentrasi $20 \%$ tepung cangkang rajungan dan $0 \%$ Ttepung eceng gondok.

B: Pakan dengan konsentrasi $10 \%$ tepung cangkang rajungan dan $10 \%$ tepung eceng gondok.

C: Pakan dengan konsentrasi $0 \%$ tepung cangkang rajungan dan 20\% tepung eceng gondok.

\section{Kadar Lemak}

Pengujian kadar lemak dalam setiap formulasi pakan menunjukkan nilai yang bervariasi. Perlakuan $\mathrm{K}$ memiliki kandungan lemak tertinggi yaitu $6,63 \%$. Nilai kadar lemak untuk tiga perlakuan lain yaitu A, B, dan C masing-masing 5,42\%, $4,55 \%$, dan $3,42 \%$. Jika dibandingkan dengan nilai maksimal pada SNI 01-39312006, maka semua perlakuan memenuhi syarat karena lebih kecil dari $7 \%$.

Tingginya kadar lemak pada pakan yang dihasilkan disebabkan karena masih terdapat kandungan lemak pada tepung ikan yang digunakan ini terlihat dari kenampakan tepung ikan yang masih terlihat basah berminyak. Selain itu, kandungan lemak dari bahan baku lain yang digunakan seperti yang terdapat pada bahan tepung bungkil kelapa. Nilai rata-rata kandungan lemak pada pakan yang dihasilkan dapat dilihat pada Gambar 3 sebagai berikut. 


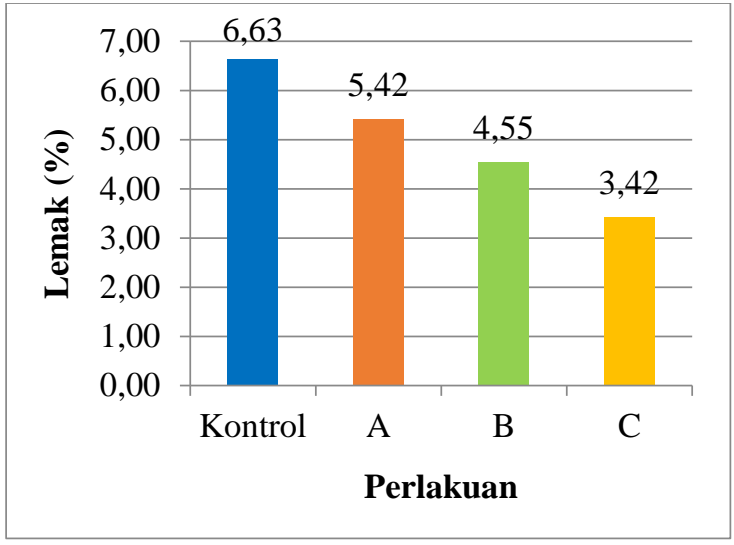

Gambar 3. Kandungan lemak pakan yang dihasilkan

Keterangan:

$\mathrm{K}$ : Pakan tanpa penambahan tepung cangkang rajungan dan tepung eceng gondok.

A: Pakan dengan konsentrasi $20 \%$ tepung cangkang rajungan dan $0 \%$ tepung eceng gondok.

B: Pakan dengan konsentrasi $10 \%$ tepung cangkang rajungan dan $10 \%$ tepung eceng gondok.

C: Pakan dengan konsentrasi 0\% tepung cangkang rajungan dan 20\% tepung eceng gondok.

\section{Kadar Kalsium}

Kadar kalsium terhadap setiap formulasi pakan menunjukkan nilai yang berbeda jauh. Perlakuan A merupakan perlakuan yang memiliki nilai kadar kalsium tertinggi yaitu 5,30\%. Nilai kadar kalsium untuk tiga perlakuan lain yaitu $\mathrm{K}$, $\mathrm{B}$, dan, $\mathrm{C}$ masing-masing, 2,54\%, 3,64\%, dan $1,35 \%$. Hal ini dikarenakan penggunaan tepung cangkang rajungan sebesar $20 \%$, sementara diketahui bahwa cangkang rajungan memiliki kandungan kalsium yang tinggi sebesar 19,97 \% (Vita, 2013). Rata-rata nilai kandungan kalsium pada pakan yang dihasilkan dapat dilihat pada Gambar 4.

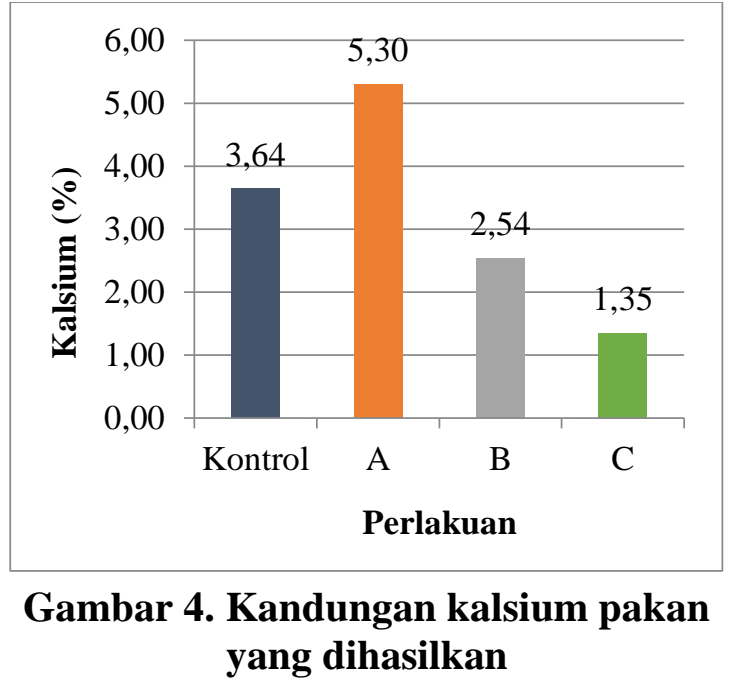

Keterangan:

K: Pakan tanpa penambahan tepung cangkang rajungan dan tepung eceng gondok.

A: Pakan dengan konsentrasi 20\% tepung cangkang rajungan dan $0 \%$ tepung eceng gondok.

B: Pakan dengan konsentrasi $10 \%$ tepung cangkang rajungan dan $10 \%$ tepung eceng gondok.

C: Pakan dengan konsentrasi $0 \%$ tepung cangkang rajungan dan $20 \%$ tepung eceng gondok.

Jika dibandingkan dengan nilai kadar kalsium maksimal pada SNI 01-3931-2006, maka semua perlakuan tidak ada yang memenuhi syarat karena lebih besar dari 1,20\%. Akan tetapi, pada kadar kalsium pada perlakuan $\mathrm{C}$ mendekati standar SNI yaitu sebesar $1,35 \%$.

\section{Simpulan}

Berdasarkan hasil penelitian, maka dapat disimpulkan bahwa subtitusi tepung cangkang rajungan dan eceng gondok pada pakan ayam yang dihasilkan memiliki kandungan nutrisi yang mendekati standar SNI yaitu pada perlakuan $\mathrm{C}$ dengan nilai kadar protein $26,32 \%$, kalsium $1,35 \%$, 
lemak 3,42\%, dan kadar air 4,12\%. Pemanfaatan cangkang rajungan dan eceng gondok sebagai sumber kalsium dalam bentuk tepung memberi kemudahan kepada masyarakat dalam mencari bahan alternatif pakan untuk pemenuhan kebutuhan asupan kalsium pada pakan ayam. Selain itu, hal ini juga memberikan nilai guna terhadap cangkang rajungan yang semula hanya menjadi limbah hingga akhirnya dapat memberikan manfaat.

\section{Daftar Pustaka}

Awaliah R, Subari Y, dan Andi S. 2017. Analisis Sifat Fisiko Kimia Nugget Rajungan (Portunus pelagicus) dengan Berbagai Bahan Pengisi. Universitas Negeri Makassar, Vol. 3 (2).

Baye A, Sompie FN, Bagau B, Regar N. 2015. Penggunaan Tepung Limbah Pengalengan Ikan Dalam Ransum Terhadap Performa Broiler. ZOOTEC. 35(1), 96-105.

Bintang IAK, Sinurat AP, Purwadaria T. 2007. Penambahan ampas mengkudu sebagai senyawa bioaktif terhadap performans ayam broiler. JITV. 12(1): $1-5$.

Dani NP, Budiharjo A, Listyawati S. 2005. Komposisi Pakan Buatan Untuk Meningkatkan Pertumbuhan Dan Kandungan Protein Ikan Tawes (Puntius javanicus blkr.) BioSMART: Journal of Biological Science. 7(02).

Efendi B. 2011. Pengaruh Penggunaan Ampas Kecap Sebagai Subtitusi Bungkil Kedelai Dalam Ransum Terhadap Nilai Kecernaan Ayam Pedaging Broiler Periode Grower. [Doctoral dissertation]. Universitas Islam Negeri Maulana Malik Ibrahim.
Hidayat MN. 2017. Respon Biologis Broiler Terhadap Pemberian Berbagai Level Tepung Cangkang Kepiting. JiiP. 3(1).

Irnawati I, Yanto S. 2018. Modifikasi alat tangkap rajungan (Portunus pelagicus) dalam meningkatkan hasil tangkapan nelayan. Jurnal Pendidikan Teknologi Pertanian. 3, 30-39.

Kusumawati E. 2014. Evaluasi Nilai Nutrisi Limbah Rajungan dan Kajian Potensi Sebagai Pakan Unggas. [Skripsi]. Mataram: Fakultas Peternakan Universitas Mataram.

Mahmilia FERA. 2005. Perubahan Nilai Gizi Tepung Eceng Gondok Fermentasi Dan Pemanfaatannya Sebagai Ransum Ayam Pedaging. JITV. 10(2), 90-95.

Mahmud MK, Hermana. 2009. Tabel Komposisi Pangan Indonesia. Persatuan Ahli Gizin Indonesia. Jakarta

Nurjannah N, Yanto S, Patang. 2018. Pemanfaatan Keong Mas (Pomacea canaliculata L) Dan Limbah Cangkang Rajungan (Portunus Pelagicus) Menjadi Pakan Ternak Untuk Meningkatkan Produksi Telur Itik. Jurnal Pendidikan Teknologi Pertanian. 3(2), 137-147.

SNI. 2006. Pakan Ayam Ras Pedaging Masa Akhir (Broiler finisher). Standar Nasional Indonesia. SNI 013931-2006. Badan Standarisasi Nasional. Jakarta; 2.

Vita Y. 2013. Tepung Cangkang Rajungan (Portunus Pelagicus) Sebagai Sumber Kalsium. Juristek. 2 (1): 185-194. 
Halaman ini sengaja dikosongkan 